\author{
Slawoj Tanaś \\ Katedra Geografii Miast i Turyzmu \\ Uniwersytet Łódzki \\ 90-142 Łódź, ul. Kopcińskiego 31 \\ slatan@geo.uni.lodz.pl
}

\section{CMENTARZ JAKO PRZEDMIOT ZAINTERESOWAŃ GEOGRAFII TURYZMU}

\section{THE CEMETERY AS A PART OF THE GEOGRAPHY OF TOURISM}

\begin{abstract}
Zarys treści: Artykuł zawiera próbę syntezy dotychczasowych badań nad walorami turystycznymi cmentarzy oraz próbę określenia miejsca cmentarza w przestrzeni geograficznej i turystycznej. Jednocześnie poruszony został problem stosunku człowieka do turystyki odbywającej się w ramach przestrzeni cmentarza, będącego obiektem zainteresowań turysty. Synteza oparta została na literaturze i prowadzonych przez autora badaniach nad walorami turystycznymi cmentarzy, m.in. z I wojny światowej w Beskidzie Niskim.
\end{abstract}

Słowa kluczowe: cmentarz, przestrzeń geograficzna, przestrzeń turystyczna, walor turystyczny, atrakcja turystyczna.

\section{WSTĘP}

Cmentarz nie był dotąd przedmiotem odrębnych badań geograficznych, w których ujmowany byłby w sposób kompleksowy. Dotychczasowe opracowania ograniczały się $\mathrm{w}$ zasadzie do pojedynczych cmentarzy lub ich grup w obrębie wybranego regionu lub miasta.

Zakres badań geografii turyzmu obejmuje m.in. przydatność przestrzeni geograficznej dla potrzeb ruchu turystycznego, strukturę i rozmieszczenie ruchu turystycznego, postawy turystów wobec określonych form i sposobów uprawiania turystyki, procesy zachodzące $\mathrm{w}$ przestrzeni geograficznej pod wpływem zjawisk turystycznych (WARSZYŃSKA 1986).

W ramach wymienionych zagadnień autor umieszcza cmentarz, będący walorem antropogenicznym oraz stanowiący cel migracji turystycznych. Nawiązując do wymienionych zagadnień, autor wyznaczył cele $w$ ramach prowadzonych badań nad znaczeniem cmentarzy w przestrzeni geograficznej i turystycznej. Są to m.in: typologia
Abstract: The article reviews research into the tourism resource of cemeteries and establishes the place they occupy in geographical and tourism space. At the same time the author discusses attitudes to 'cemetery space' of interest from a tourism perspective. The review is based on the literature and the author's study of the tourism resources of cemeteries such as those from World War I in the Beskid Niski range of hills.

Key words: cemetery, geographical space, tourism space, tourism resource, tourism attraction.

\section{INTRODUCTION}

Until now cemeteries have not been considered in a comprehensive way as objects of specific geographical study. Existing publications are in fact limited to descriptions of individual cemeteries or their distribution within a chosen region or city. The geography of tourism includes the study of the usefulness of geographical space for tourism purposes, of the structure and distribution of tourism, tourist attitudes towards given forms of tourism, and processes in geographical space produced by tourism phenomena (WARSZYŃSKA 1986).

The author discusses cemeteries in terms of these issues, and as an anthropogenic resource and a tourism destination. The author sets out such research objectives as establishing the importance of cemeteries in geographical and tourism space, establishing a typology of cemeteries, creating a model of their func- 
cmentarzy, stworzenie modelu zmian funkcjonalnych cmentarzy, badanie ruchu migracyjnego na cmentarzach, badanie procesów zachodzących na cmentarzach pod wpływem ruchu turystycznego, badanie stopnia i charakteru zainteresowania polskiego społeczeństwa cmentarzami.

W niniejszym artykule autor postara się odpowiedzieć na następujące pytania: Jakie zależności występują między przestrzenią geograficzną a cmentarzem? W jakim stopniu cmentarz jest walorem turystycznym i czy może stanowić atrakcję turystyczną? Jak zmienia się percepcja cmentarza wraz ze zmianą wieku odwiedzających?

Cmentarz z racji pełnionych funkcji oraz przyjmowanych kryteriów klasyfikacji, jest różnie traktowany $\mathrm{w}$ publikacjach naukowych. W strukturze przestrzenno-funkcjonalnej miasta cmentarz zaliczany jest do terenów zieleni, zieleni i rekreacji, zieleni urządzonej, terenów zieleni wypoczynkowej, zieleńców i cmentarzy, urządzeń kultury fizycznej, terenów własności publicznej i półpublicznej, terenów użyteczności publicznej, terenów usług, terenów gospodarki komunalnej, terenów technicznych i specjalnych, terenów przestrzeni otwartej (LISZEWSKI 1973).

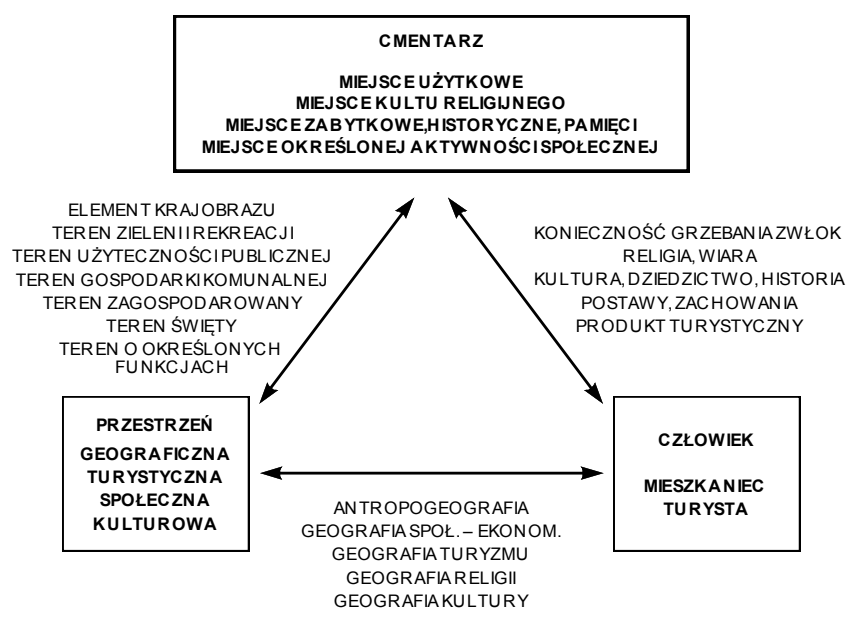

Rys. 1. Zależności między przestrzenia, człowiekiem a cmentarzem (opracowanie własne)

W klasyfikacjach walorów turystycznych cmentarz zaliczany jest do walorów antropogenicznych, w ramach których rozróżniany jest jako walor kulturowy (organizacja i sposób życia grup społecznych, dziedzictwo kulturowe), walor dóbr kultury (zabytek architektury, budownictwa i urbanistyki, zabytek archeologiczny), walor historyczny (pamiątka histo- tional change, studying tourism and the processes produced by it, as well as the extent to which Polish society is interested in cemeteries.

The following questions are considered: "What is the relation between geographical space and the cemetery?', 'To what extent is a cemetery a tourism resource and can it be a tourism attraction?' and 'How does the perception of a cemetery change depending on the age of the visitor?'

Due to the variety of functions a cemetery performs, and the particular land use classification criteria adopted, they are treated in various ways in academic publications. In the urban spatialfunctional structure they occupy a number of categories including those focusing on recreation, the environment and public services (LISZEWSKI 1973).

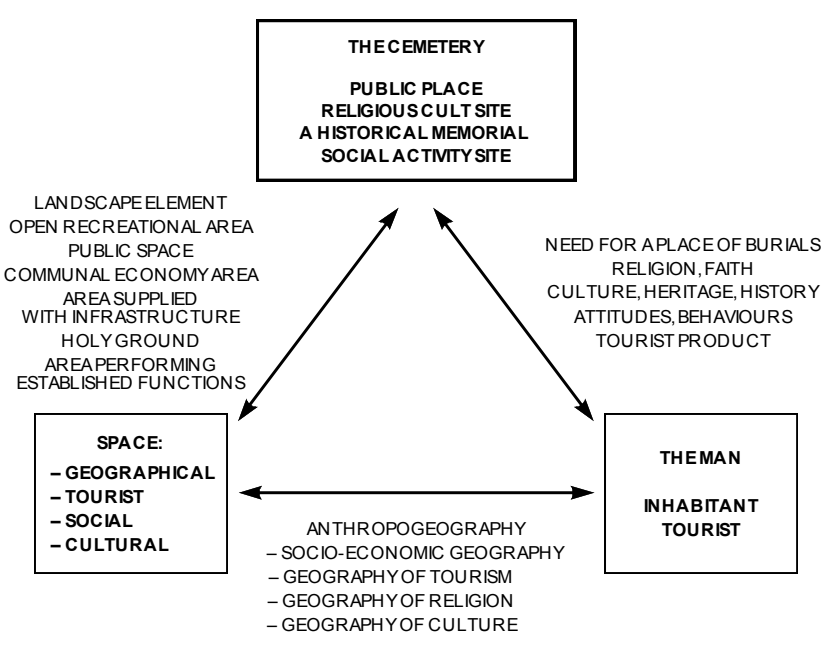

Fig. 1. Relations between geographical space, society and the cemetery (s o u r c e: author)

In a classification of tourism resources, a cemetery is an anthropogenic and a socio-cultural resource (the organisation and way of life of social groups, cultural heritage), a material culture resource (an architectural and urban planning monument, an archaeological monument), a historical resource (a historical relic, national memorial site), a tourism resource (of educational, aesthetic, didactic and national significance), and a religious resource 
ryczna, miejsce pamięci narodowej), walor krajoznawczy (znaczenie poznawcze, estetyczne, dydaktyczne i patriotyczne), walor religijny (miejsce kultu religijnego) (RoGALEWSKI 1979, PRZYBYSZEWSKA-GUDELIS i in. 1979, KRUCZEK 1997, GAWORECKI 2000). Występujące zależności i wzajemne powiązania pomiędzy przestrzenią geograficzną, człowiekiem a cmentarzem prezentuje rys. 1 .

\section{CMENTARZ JAKO OBIEKT KRAJOZNAWCZY}

Aby zrozumieć znaczenie walorów krajoznawczych cmentarza, niezbędne jest przybliżenie tych zagadnień, poprzez które nekropolia staje się istotną częścią historii, kultury, sztuki i krajoznawstwa.

Cmentarz jest przede wszystkim miejscem spoczynku zmarłych i pamięci o nich. Jest dokumentem historii i dziedzictwem kultury. Tu możemy znaleźć informacje o przeszłości danego miejsca, historii ludzi, ich pochodzeniu, czynach i minionym życiu. Jest źródłem informacji biograficznych i historycznych.

Cmentarz jest instytucjonalnie ukształtowanym wycinkiem przestrzeni o programowo założonym grzebalnym przeznaczeniu, zorganizowanym wedle pewnych dyrektyw - reguł kul-urowych, związanych $\mathrm{z}$ rytuałem grzebania zmarłych oraz $\mathrm{z}$ istnieniem różnych tradycji sposobu utrwalania pamięci o nich (KolbUSZEWSKI 1996). Cmentarz, będący zbiorem mogił, ma znaczenie również dla dziedzictwa narodowego, dla zachowania i przekazania następnym pokoleniom świadectwa historii, źródeł i dokumentów; jest cennym zabytkiem architektonicznym, na który składają się rzeźby, pomniki, nagrobki, grobowce lub kaplice, świadczące o cechach i pochodzeniu zmarłego lub o okresie, w którym powstały.

Cmentarz dobrze zorganizowany to założenie ogrodowe $z$ oprawą architektoniczną i rzeźbiarską. Pełni funkcje ekologiczne i jako skupisko zieleni stanowi trwały element krajobrazu oraz wpływa korzystnie na środowisko przyrodnicze. Daje szanse przetrwania, zwłaszcza w miastach, licznym gatunkom roślin i ptaków. Często wśród drzew spotyka się pomniki przyrody. Jest to ogrodzony układ przestrzenny, regularny lub swobodny, posiadający oś kom- (a religious cult site) (RogALEWSKI 1979, PRZYBYSZEWSKA-GUDELIS et al. 1979, KRUCZEK 1997 and GAWRECKI 2000). The relations between geographical space, society and a cemetery are presented in fig. 1 .

\section{THE CEMETERY AS A TOURISM SITE}

In order to understand the tourism resource of a cemetery, the author discusses the term itself and the differing types which play an important part in history, culture, art and tourism. The cemetery is above all a resting place for the dead and a remembrance site. It is cultural heritage and a historical document. It provides information about the past of a place, the history of those who lived there, their origins, deeds and past lives. It is a source of biographical and historical information.

A cemetery is an institutionally established part of space performing a burial function, according to specific cultural principles regarding the burial ritual, and differing traditions of commemorating those who have died (KOLBU-SZEWSKI 1996). A cemetery is also important for preserving and passing on national heritage to subsequent generations, and as a historical source and document. It is a valuable architectural monument with sculpture, monuments, graves, tombs and chapels telling the story of the character and life of the dead, and of the period in which the monument was erected.

A well-organised cemetery is a 'garden' with strong architectural and sculptural elements. It performs an ecological function and as a green open area it is a permanent element of the landscape benefiting the natural environment. It offers a chance for survival to many species of plants and birds, especially in cities, and natural 'monuments' are often found among the many trees. It is a bounded area of space, planned or unplanned, with a main axis from which smaller paths depart dividing 
pozycyjną, od której odchodzą alejki dzielące teren najczęściej na kwartały. Centralnymi elementami są zazwyczaj krzyż, pomnik lub kaplica.

Całość kompozycyjna cmentarza decyduje o tym, że należy go traktować jako ,zespół krajoznawczy" (MACZUBSKi 1989).

Pierwsze zapisy słowa „cmentarz” pojawiają się w Polsce w XVI w., wcześniej był to „cmynterz” lub „cmyntarz”. Lacińskie cimiterium pochodzi od greckiego koimeterion - sypialnia, miejsce spoczynku (Koimao - śpią, Tereo - ochraniam), miejsce ochraniające (BAŃKOWSKI 2000). Według Uniwersalnego stownika języka polskiego (DUBISZ 2003) cmentarz to miejsce zwykle ogrodzone, gdzie grzebani są zmarli lub przechowywane są prochy po ich kremacji, przestrzeń, plac wokół kościoła (gdzie dawniej grzebano zmarłych), dziedziniec kościelny.

„Nekropolia” to starożytny lub wczesnochrześcijański cmentarz, położony zwykle w pobliżu wielkiego miasta. Duży i zabytkowy cmentarz, na którym pochowani są członkowie znanych rodów i ludzie sławni. Necropolis to nazwa wielkiego cmentarza koło Aleksandrii w Egipcie (dosł. miasto zmarłych) (BAŃKO 2003). Najczęściej określenie „nekropolia” przyporządkowane jest dużym cmentarzom o założeniach ogrodowych, których układ przestrzenny odwzorowuje model przestrzeni miejskiej, a więc główne ulice, mniejsze uliczki, alejki, place, centralne skwery, zabudowę niską i wysoką.

Najstarsze w Europie zapisy norm prawnych określających zasady lokalizacji cmentarzy pojawiają się w V w. p.n.e. Wówczas rzymskie prawo nakazywało zakładanie cmentarzy poza obrębem miasta i uznawało je za miejsca święte i nietykalne.

Cmentarze chrześcijańskie pojawiają się w III w. n.e. Konsekrowane lub poświęcone, jako miejsca święte chronione były immunitetem. Obejmowało je także prawo azylu. Prawo to czyniło cmentarz, podobnie jak kościół, miejscem schronienia dla wszystkich, również żywych, a w szczególności ściganych.

Do VI w. nie było tradycji lokowania cmentarzy przy kościołach czy w obrębie miast. Były to często miejsca niegrodzone, nie posiadające specjalnych założeń. Począwszy od Synodu w Bradze w 563 r., cmentarze lokowane są w obrębie miast i sąsiedztwie kościołów, a od IX w. przy- it into sectors. The central element is usually a cross, a monument or a chapel. It is the compositional whole that makes it a 'tourism complex' (MACZUBSKI 1989).

The first records of the word cmentarz (cemetery) in Poland appeared in the $16^{\text {th }} \mathrm{c}$, earlier it was cmynterz or cmyntarz. The Latin cimiterium comes from the Greek koimeterion - a dormitory, a resting place (Koimao - they are asleep), and a protecting site (Tereo - I protect) (BAŃKOWSKI 2000). According to Uniwersalny słownik jezyka polskiego (Universal Dictionary of Polish Language - DUBISZ 2003), a cemetery is usually a bounded place where the dead are buried or their ashes placed after cremation; the space around the church (where people were formerly buried) is known as the churchyard.

A necropolis is an ancient or early Christian cemetery, usually situated near a large city. They are large historical cemeteries where members of renowned families and famous individuals were buried. Specifically Necropolis is the name of a large cemetery near Alexandria in Egypt (meaning the city of the dead) (BAŃKO 2003). Most often the term is used in reference to large, garden cemeteries whose spatial organisation reflects urban space itself with main streets, side streets, avenues, squares including a central one, and both high and low buildings.

The oldest European legal regulations regarding the location of cemeteries appeared in the $5^{\text {th }}$ c. B.C. when Roman law allowed cemeteries to be built outside the city, and regarded them as holy and untouchable sites. Christian cemeteries appeared in the $3^{\text {rd }}$ c. A.D. with immunity as consecrated holy places and a place of refuge for anybody, similar to churches, and especially for those outside the law.

Until the $6^{\text {th }} \mathrm{c}$. there was no tradition of situating cemeteries near churches or within cities and they were often without boundaries and unplanned. After the Prague Synod in 563, cemeteries began to be established within cities and near churches, and from the $9^{\text {th }} \mathrm{c}$. the churches themselves were used for burials as well. The Rome Synod in 1059 gave cemeteries the status of consecrated ground and 
jął się zwyczaj grzebania zwłok również w kościołach. Sobór Rzymski z 1059 r. nadał cmentarzom rangę „pól świętych”, rzucając klątwę na bezczeszczących je. Taka sytuacja trwała do połowy wieku XVIII, kiedy to $\mathrm{w}$ wielu miastach europejskich cmentarze były często przepełnione. Zdarzało się, że zwłoki grzebano na cmentarzach przykościelnych, przez setki lat nie powiększając ich powierzchni. W miastach europejskich $\mathrm{w}$ dużej mierze $\mathrm{z}$ tego powodu unosił się znaczny odór, a płytko grzebane zwłoki stanowiły zalążek wielu epidemii. Uciążliwe skutki egzystowania społeczeństwa miejskiego w tych warunkach były przyczyną zamykania od wieku XVIII cmentarzy przykościelnych, zakazu grzebania w pobliżu kościołów i przenoszenia cmentarzy poza obręb miasta. $Z$ tych względów powstały w drugiej połowie XVIII w. również polskie nekropolie, m.in. w Krakowie, Warszawie, Lwowie czy Wilnie. Od tego czasu cmentarze lokowane są poza obrębem miasta lub wsi. Ich lokalizacja jest planowana i podlega prawnym regułom.

Cmentarz spełniał nieraz liczne wtórne funkcje, sprzeczne $\mathrm{z}$ jego podstawową rolą i charakterem. W średniowieczu na cmentarzach przykościelnych, stanowiących często centralne miejsce w mieście, odbywały się jarmarki i zabawy, sądy, sejmiki, procesy, kazania, misteria, przedstawienia, obrzędy ludowe, egzekucje czy manifestacje. Jednakże zawsze cmentarz stanowił miejsce powagi, pamięci i szacunku. A każdy przejaw profanacji spotykał się $\mathrm{z}$ ostrą reakcją lokalnej społeczności.

Według Głównego Urzędu Statystycznego cmentarze dzielimy na cmentarze czynne, nieczynne, wydzielone i niewydzielone. Za cmentarz wydzielony uważa się cmentarz stanowiący oddzielną działkę terenową, oddzieloną od terenów o innym sposobie użytkowania ogrodzeniem lub liniami regulacyjnymi. Za cmentarz niewydzielony uznaje się cmentarz znajdujący się na terenie innego obiektu, np. szpitala, klasztoru, zakładu penitencjarnego czy kościoła. Cmentarz czynny to taki, na którego terenie odbywa się grzebanie zwłok zarówno w ziemi, jak i w grobowcach. Za cmentarz nieczynny uznaje się obiekt, dla którego została wydana decyzja władz komunalnych o zamknięciu lub o przeznaczeniu terenu na inny cel.

$\mathrm{Na}$ podstawie zarówno prowadzonych badań, jak i klasyfikacji MACZUBSKIEGO (1989) i KoLBUSZEWSKIEGO (1996) autor grupuje polskie excommunicated those who desecrated them. This was the situation until the mid $18^{\text {th }} \mathrm{c}$. by which time in many European countries cemeteries had become overcrowded and there were situations where burials had taken place in unenlarged church graveyards for hundreds of years. Partly for this reason European cities stank and the shallowly buried bodies were the cause of many epidemics. As a result from the $18^{\text {th }} \mathrm{c}$. church graveyards were closed and those who could not be buried there were put in cemeteries outside the city walls. This was how in the second half of the $18^{\text {th }} \mathrm{c}$. some Polish necropolises appeared, e.g. in Kraków, Warsaw, Lvov and Vilnius. From that time cemeteries were situated outside cities, towns or villages, their location planned and subject to certain legal regulations.

The cemetery has often performed differing secondary functions often contrary to its primary role and character. In the Middle Ages church graveyards, often the central points in cities, were the sites of fairs and festivities as well as being used for local parliaments, trials, preaching, miracle play performances, folk rites, executions or demonstrations. However the cemetery has always been a place of solemnity, remembrance and respect, and anyone profaning them has been ostracised by the community.

According to the Polish Statistical Office, cemeteries are divided into 'active', 'inactive', 'independent' and 'incorporated'. An 'independent' cemetery is one which is on an individual plot of land, separated from areas used differently by means of fencing or regulated boundary lines. An incorporated' cemetery is one which is part of another area, belonging to e.g. a hospital, monastery, prison or church. An 'active' cemetery is one where bodies are currently being buried (both in the ground and in tombs) while an 'inactive' cemetery has been formally closed or is used for other purposes.

Based on the author's research, and MACZUBSKI's (1989) and KOLBUSZEWSKI's (1996) classifications, Polish cemeteries are divided into groups according to the functions they perform, their character and location. 
cmentarze na podstawie pełnionej funkcji, charakteru oraz lokalizacji w następujące typy:

Cmentarze cywilne - służące do grzebania ogółu zmarłych:

1) cmentarze komunalne, świeckie - przeznaczone dla wszystkich mieszkańców określonej miejscowości, niezależnie od wyznania, administrowane przez urząd gminy lub miasta.

2) wyznaniowe - przeznaczone dla wyznawców określonej religii:

a) cmentarze chrześcijańskie:

- rzymskokatolickie (jeden $\mathrm{z}$ najstarszych na ziemiach polskich czynny jeszcze cmentarz rzymskokatolicki - cmentarz Powązkowski w Warszawie, założony w 1790 r.) oraz grekokatolickie (np. w Beskidzie Niskim),

- prawosławne - wśród nich starowierców (np. w Wojnowie, Gabowych Grądach),

- protestanckie - ewangelicko-augsburskie (do najstarszych ewangelickich cmentarzy należy cmentarz we Wschowie z 1609 r.),

- ewangelicko-reformowane, kalwińskie, luterańskie, mennonickie (np. Żuławy) i inne;

- mariawickie i inne;

b) cmentarze niechrześcijańskie:

- żydowskie - kirkut (np. w Tykocinie z roku 1522, Krakowie sprzed 1551 r.),

- muzułmańskie - mizar (np. w Warszawie, Bohonikach, Kruszynianach),

- karaimskie - zeret i inne;

c) przykościelne (ogrójec) - na przełomie XVIII/ XIX w. były likwidowane w miastach ze względów sanitarnych;

d) wewnątrzkościelne - grobowce, epitafia, kaplice grobowe, katakumby;

e) kościelne - wydzielone i utrzymywane przez odpowiednią jednostkę organizacji kościelnej;

f) parafialne - przeznaczone dla wyznawców $\mathrm{z}$ danej parafii;

g) ogólne - przeznaczone dla wyznawców $\mathrm{z}$ różnych parafii;

h) polne - zakładane poza terenem kościelnym;

Inne cmentarze to:

1) cmentarze wojskowe - przeznaczone dla wojskowych, zakładane i administrowane przez określoną jednostkę wojskową, m.in. garnizonowe i ogólne;

2) cmentarze ofiar terroru - cmentarze ludności cywilnej, mordowanej przez zaborców i okupantów w XIX i XX w., zwłaszcza przez Niemców hitlerowskich podczas II wojny światowej (np.
Civil cemeteries - for the burial of all the dead:

1) communal or secular cemeteries for all the inhabitants of a given area, irrespective of their religion and administered by the local authorities.

2) cemeteries of various religions - for the burial of respective believers:

a) Christian cemeteries:

- Roman Catholic (one of the oldest active in Poland is the Powazki Cemetery in Warsaw, set up in 1790), Greek Catholic (e.g. in the Beskid Niski);

- orthodox, including Old Believers (e.g. in Wojnów and Gabowe Grądy);

- protestant - Evangelical-Augsburg (one of the oldest Evangelical cemeteries is from 1609 in Wschowa), Evangelical Reformed, Calvinist, Lutheran, Mennonite (e.g. in Żuławy) and others;

- Mariavite and others;

b) non-Christian cemeteries:

- Jewish - kirkut (e.g. in Tykocin from 1522, in Kraków from before 1551);

- Muslim - mizar (e.g. in Warsaw, Bohoniki and Kruszyniany);

- Karaite - zeret;

c) church graveyards - closed from the beginning of the $19^{\text {th }}$ century for sanitary reasons;

d) in-church burials - tombs, epitaphs, chapels, catacombs;

e) church cemeteries - maintained by an appropriate department of the church authorities;

f) parish cemeteries - for the inhabitants of individual parishes;

g) 'open' cemeteries - for the inhabitants of different parishes;

h) 'field' cemeteries - set up outside church grounds;

Other cemeteries:

1) military cemeteries - for soldiers, set up and administered by military units e.g. garrison;

2) cemeteries for the 'victims of terror' for ordinary citizens murdered in the times of the Polish partition in the 19th and $20^{\text {th }}$ c., and particularly by the German Nazis during World War II (e.g. Oświęcim (Auschwitz) and Majdanek). Often in the form of symbolic cemeteries (e.g. the War- 
Oświęcim, Majdanek); często tworzone w postaci cmentarzy symbolicznych (np. Cytadela Warszawska, Palmiry);

3) cmentarze wojenne - przeznaczone dla osób poległych w wyniku działań wojennych. Administrowane przez urzędy gminy lub miasta. Cmentarze wojenne posiadają charakterystyczne rozplanowanie. Groby pojedyncze i zbiorowe rozmieszczone są w kwaterach. Często występują nagrobki lub pojedyncze krzyże. Dominantą jest pomnik lub inny centralny obiekt (np. cmentarze wojenne Beskidu Niskiego);

4) cmentarze ufortyfikowane - lokalizowane na terenie zamku lub twierdzy w XIV-XVIII w. (np. w Sudetach, na Dolnym Śląsku);

5) cmentarze prywatne - powstałe na terenach prywatnych rezydencji pałacowych w XIX w.;

6) cmentarze przyszpitalne i epidemiczne powstałe na terenach szpitalnych, przeznaczone dla zmarłych pacjentów lub zbiorowe mogiły ludności zmarłej w wyniku epidemii (np. Czermna k. Kudowy Zdr.);

7) cmentarze zakonne i przyklasztorne - (np. katakumby klasztorne Franciszkanów);

8) cmentarze symboliczne i pomniki, tzw. cenotafy lub lapidaria (np. Grób Nieznanego Żołnierza w Warszawie, Poznańska Cytadela, lapidarium żydowskie w Chełmnie nad Nerem);

9) cmentarze zasłużonych - (np. Stary Cmentarz w Zakopanem, Aleja Zasłużonych na Powązkach w Warszawie);

10) cmentarze wirydarzowe typu Campo Santo (np. Cmentarz Orląt Lwowskich we Lwowie);

11) cmentarze ogrodowe i parkowe - o założeniach parkowo-ogrodowych (np. cmentarz Rakowicki w Krakowie);

12) cmentarze wiejskie - małe cmentarze przykościelne lub lokalizowane na peryferiach wsi;

13) cmentarze miejskie - lokalizowane na peryferiach miast;

14) miejskie nekropolie - miasta umarłych, po raz pierwszy powstałe we Francji i Portugalii w XIX w. na kanwie rozwoju procesów urbanistycznych (np. cmentarz Rakowicki w Krakowie, Powązki w Warszawie);

15) pojedyncze i samotne mogiły (np. w Puszczy Kampinoskiej);

16) cmentarze zwierząt.

$\mathrm{Na}$ wystrój cmentarza składa się wiele elementów, które razem tworzą architektoniczną tożsa- saw Citadel and Palmiry);

3) war cemeteries - for people killed during a war and administered by local authorities. War cemeteries are arranged in a characteristic way with single and collective graves organised in sectors. There are many gravestones and individual crosses, and a monument or other central object is the dominant feature (e.g. war cemeteries in the Beskid Niski);

4) fortified cemeteries - situated within a castle or stronghold in the $14^{\text {th }}-18^{\text {th }} \mathrm{c}$. (e.g. in the Sudety Mountains or in Lower Silesia);

5) private cemeteries - set up in the private grounds of palaces in the $19^{\text {th }} \mathrm{c}$.;

6) hospital and epidemic cemeteries - set up within hospital premises for deceased patients, or collective graves for those who died as a result of epidemics (e.g. Czermna near Kudowa Zdrój);

7) monastery cemeteries - e.g. the Franciscan catacombs;

8) symbolic cemeteries and monuments, known also as cenotaphs or 'lapidaria' (e.g. the 'Tomb of the Unknown Soldier' in Warsaw, Poznan Citadel and the Jewish 'lapidarium' in Chelmno on the Ner River);

9) cemeteries for 'distinguished' people e.g. the Old Cemetery in Zakopane and Aleja Zasłużonych in Powazki cemetery in Warsaw;

10) cloister cemeteries of the 'Campo Santo' type (e.g. the Cemetery of the 'Lvov Eagles' in Lvov);

11) garden or park cemeteries - e.g. the Rakowicki Cemetery in Kraków;

12) rural cemeteries - small cemeteries near churches or outside villages;

13) city cemeteries - situated on the city periphery;

14) city necropolises - 'cities of the dead', first appearing in France and Portugal in the $19^{\text {th }}$ c. as part of urban planning processes (e.g. the Rakowicki Cemetery in Kraków, Powazki in Warsaw);

15) individual and isolated graves - e.g. in the Kampinoski Forest;

16) animal cemeteries.

A cemetery consists of many elements which together give its architectural identity: 
mość nekropolii. Najważniejsze i najczęściej występujące to:

1) trwałe ogrodzenie - spełnia funkcję ochronną przed profanacją cmentarza; zawsze posiada centralną (główną) bramę;

2) kaplica cmentarna - służy do odprawiania ceremonii pogrzebowych, pełni niekiedy także funkcję kostnicy (w dawnych czasach miejsce przechowywania szczątków kostnych wydobytych podczas kopania nowych mogił). Na cmentarzu komunalnym odpowiednikiem kaplicy jest dom pogrzebowy.

3) główna aleja - tworzy oś kompozycyjną; wraz z bocznymi alejkami dzieli cały cmentarz na kwatery, zazwyczaj prostokątne. Kwatery mogą posiadać swoją specyfikę, rozróżniamy np. kwatery zasłużonych, wojenne, dziecięce, urnowe lub inne.

4) grób - jest miejscem pochówku zmarłego, może posiadać różne formy: ziemne, murowane, pojedyncze lub zbiorowe (rodzinne), urnowe. Istnieją również cenotafy, czyli groby symboliczne, będące formą upamiętnienia osoby, która pochowana jest $\mathrm{w}$ innym miejscu lub której ciała nie odnaleziono. Elementem zdobiącym grób i informacyjnym jest nagrobek. Na cmentarzach chrześcijańskich nagrobek ma postać krzyża, płyty kamiennej, kamienia, głazu lub pomnika nagrobnego $z$ umieszczoną inskrypcją $i$ informacją o zmarłym (data urodzenia i śmierci, imię i nazwisko itp.). Nagrobki żydowskie (maceby, macewy) mają postać kamiennej płyty pionowo postawionej, zakończonej łukowato, płasko lub trójkątnie. Zdobione są ornamentyką lub płaskorzeźbą przedstawiającą zalety zmarłego. Nagrobki muzułmańskie posiadają formę stojącej płyty kamiennej lub kolumny z inskrypcją pisaną alfabetem arabskim, z półksiężycem lub gwiazdą pięcioramienną.

5) grobowce - są budowlami składającymi się z części podziemnej (komory grobowej) i naziemnej (kaplicy) odpowiednio zdobionej.

6) katakumby - są to uszeregowane rzędy w kilku kondygnacjach nisz, w których umieszczone są trumny ze zwłokami. Otwory nisz zamknięte są tablicą $\mathrm{z}$ inskrypcją i informacją o zmarłym.

7) element centralny - tworzy zazwyczaj krzyż umieszczony w centralnym punkcie cmentarza, pomnik lub kaplica.

8) oprawa roślinna - stanowiąca skupisko
1) permanent boundaries - protect the cemetery against profanation. There is always a main entrance gate;

2) cemetery chapel - used for burial ceremonies, or sometimes as a mortuary (formerly it was the storage place for bones excavated when digging new graves). At a communal cemetery the equivalent of the chapel is the 'funeral home';

3) the main avenue - the axis of the layout. Together with side 'aisles' it divides the 'cemetery into sectors - usually square. Sectors can be of different types, e.g. for distinguished' people, victims of war, children, the cremated etc.;

4) a grave is a burial place made of open soil or constructed, single or collective (family), or of those cremated. There are also cenotaphs i.e. symbolic graves which are a way of commemorating those buried elsewhere or whose bodies have not been found. The gravestone is both the decoration and information element:

- in Christian cemeteries gravestones may have the form of a cross, a stone slab, boulder or monument, with an inscription giving information about the dead person (dates of birth and death, forenames, surname, etc.);

- a Jewish gravestone (matzeba/matzewa) consists of a vertical stone slab, with an arched, flat or triangular top. They are decorated with ornaments or a low relief presenting the dead person's virtues;

- muslim gravestones have the form of a standing stone slab or column with an inscription written in Arabic, with a crescent moon or a five-pointed star;

5) tombs are constructions which consist of an underground part (the tomb chamber) and a surface part (a chapel), suitably decorated;

6) catacombs are several tiers of niches in orderly rows where coffins are placed. The niche openings are closed off by panels with inscriptions and information about the dead behind them;

7) the 'central element' is usually placed at the central point of the cemetery a cross, a monument or chapel;

8) botanical decoration - trees, bushes and flowers which make the cemetery 
drzew, krzewów i kwiatów, mających na celu wyróżnienie terenu cmentarza spośród sąsiadujących obszarów o odmiennym przeznaczeniu i funkcji, chroniące przed wiatrem, zwiększające walory estetyczne.

Wraz z rozwojem cmentarzy pojawiają się formy zdobień grobów (sarkofagi, epitafia). Rozwija się sztuka grobowa zwana sepulkralna, charakteryzująca się różnymi formami nagrobków i specyficznym zdobieniem, posiadającym swą symbolikę. Symbolika dekoracji nagrobków zaznacza się poprzez znaki, przedmioty lub pojęcia związane ze śmiercią, przemijaniem, nieśmiertelnością, żałobą lub osobistymi cechami zmarłego.

\section{CMENTARZ W PRZESTRZENI GEOGRAFICZNEJ I TURYSTYCZNEJ}

Należy zastanowić się, jakie były początki ruchu turystycznego, którego celem były cmentarze. Niewątpliwie tak jak w początkach turystyki ruch ten opierał się na wędrówkach o motywach religijnych. Elementem migracji religijnych były od początku chrześcijaństwa pielgrzymki związane z kultem grobu osób, które odegrały ważną rolę w historii i zostały uznane za błogosławione lub święte, stając się przedmiotem kultu lub pozostając $\mathrm{w}$ centrum zainteresowania społeczeństw (JACKOWSKI 2003).

Kult męczenników rozwinął się w szczególności w chrześcijaństwie zachodnim. W Polsce zjawisko to obserwujemy na przykładzie kultu św. Wojciecha (Gniezno) i św. Stanisława Biskupa (Kraków). Celem podobnych pielgrzymek lub wędrówek są również groby osób zmarłych w opinii męczeństwa lub świętości, ale niebeatyfikowanych i niekanonizowanych (np. grób prymasa Stefana Wyszyńskiego, ks. Popiełuszki), osób znanych, mających wybitne osiągnięcia i zasługi dla społeczeństwa (np. groby królów polskich, wybitnych pisarzy, artystów).

Turystyka pielgrzymkowa była często w społeczeństwach ubogich formą jedynej aktywności turystycznej, a wędrówki na cmentarze w celach turystycznych potwierdzają np. wydawane w wiekach XII-XIII przewodniki po rzymskich katakumbach.

W naszym kręgu kulturowym, w opinii autora, mamy do czynienia ze zjawiskiem pielgrzymek, których celem są cmentarze w okresie Wszyst- stand out from the surrounding area. They are a protection against wind, and intensify the aesthetic element.

As cemeteries developed through time, new forms of grave decoration appeared (sarcophagi and epitaphs) and its sepulchral art introduced new forms and characteristic symbolic ornamentation based on figures, subjects or ideas related to death, the passing of time, immortality, mourning or the personal traits of the dead person.

\section{THE CEMETERY IN GEOGRAPHICAL AND TOURISM SPACE}

The origins of cemetery tourism are worth considering and involved travel for religious purposes. From the beginning of Christianity a pilgrimage was a kind of religious tourism connected with the cult of the burial places of those who had played an important role in history and were considered beatified or a saint (JACKOWSKI 2003).

The cult of martyrs developed particularly in western Christianity. In Poland it can be found in the cases of St Wojciech (Adalbert) in Gniezno and the bishop St Stanisław (Stanislaus) in Krakow. The graves of those who died as martyrs, or of holy people who have not been officially beatified or canonised (e.g. the grave of the primate Stefan Wyszyński, or of the priest Jerzy Popiełuszko), as well as famous people of extraordinary achievement and merit (e.g. the graves of Polish monarchs, renowned writers or artists) are the goals of similar pilgrimages.

Pilgrimage tourism in poor societies was often the only form of tourism activity, and journeys to cemeteries for such purposes are confirmed, for example, in the guides to the Roman catacombs published in the $12^{\text {th }}-13^{\text {th }} \mathrm{c}$.

In Poland pilgrimages are made to cemeteries around the time of All Saints Day and other important church festivals. 
kich Świętych i najważniejszych świąt kościelnych. Takie migracje niewątpliwie zaliczymy do kategorii sacrum i obowiązku duchowego wobec osób zmarłych. Należy jednak pamiętać o świeckim aspekcie odwiedzin cmentarzy w tym czasie, np. chęci spotkania z rodziną.

Dzień Wszystkich Świętych jest często jednym $\mathrm{z}$ niewielu dni w roku, kiedy Polacy odwiedzają miejsce swego pochodzenia i wychowania. Ujawniają się więzi rodzinne, powroty do „korzeni”. Obok motywów religijnych pojawiają się motywy czysto świeckie czy egzystencjalne. Migracje te wyrażają się wzmożonym ruchem samochodów na drogach całego kraju oraz wzmożonym ruchem ludności.

Kult świętych w islamie sprawił, że stopniowo jednym z najważniejszych punktów miasta (osady) stawał się cmentarz, będący miejscem pielgrzymek, zgromadzeń i uroczystości. Ma to szczególne znaczenie $\mathrm{w}$ miejscach kultu religijnego Szyitów. Jednym $z$ elementów ich wiary jest bowiem przekonanie, że pochowanie zmarłego obok świętej osoby zapewnia mu bezpośrednie wejście do raju. W konsekwencji corocznie $\mathrm{w}$ miejscach tych grzebani są muzułmanie, których zwłoki przywożone są nieraz $\mathrm{z}$ odległych krajów. $\mathrm{W}$ ten sposób cmentarze rozrastają się, tworząc nekropolie, które nabierają większego znaczenia niż zabudowania żywych mieszkańców.

W Polsce w wiekach XI-XVI miejsca uchodzące za święte, w szczególności kościoły lub groby świętych, były obiektami zainteresowania zamożnej ludności świeckiej, która częstokroć jeszcze za życia budowała na ich terenie lub w pobliżu kaplice i grobowce przeznaczone na miejsce spoczynku dla siebie lub swoich rodzin. Dziś obiekty te stanowią częsty cel wycieczek turystycznych o charakterze poznawczym i historycznym.

Jeżeli grób, grupę grobów lub cmentarz potraktujemy jako miejsce docelowe migracji turystycznych, to uznać możemy, że mamy do czynienia ze zjawiskiem „turystyki cmentarnej”.

Należy przypomnieć, iż cechą wspólną migracji religijnych i turystycznych jest sam fakt podjęcia podróży, a więc przemieszczanie się w określonej przestrzeni, korzystanie z tych samych na ogół elementów infrastruktury, środków transportu. Różni je w sposób zasadniczy motywacja i sposób zachowań (JACKOWSKI 2003). Mogą to być podróże religijne lub religijno-poznawcze, stanowiące specyficzny typ podróży turystycznych, na-
Such tourism can certainly be included in the sacred category and seen as a spiritual obligation. The secular aspects of these visits, such as the desire for family reunion, should not be forgotten however. All Saints is one of the few days in the year when Polish people visit the place where they were born and grew up. Family ties are revived and there is a return to 'roots'. Besides religion, secular and existential motives are also often found and the day is characterised by a great number of people travelling and heavy road traffic.

The cult of Islamic saints has made the cemetery one of the most important places in an Islamic settlement which can become a pilgrimage destination as well as an assembly and ceremonial site. This is particularly important at Shiite religious sites as an element of this faith is the belief that by burying someone next to a holy person it will guarantee a direct passage to paradise. As a result every year Muslims, whose bodies are sometimes brought from faraway countries, are buried in these places. In this way these cemeteries are growing and changing into necropolises more significant than by being simply available for local inhabitants.

In Poland in the $11^{\text {th }}-16^{\text {th }}$ c. sites regarded as holy, particularly churches and the graves of saints, were popular among rich secular people who often built chapels and tombs for themselves and their families there while they were still alive. Today they are often tourism destinations for educational and historical trips.

If a grave, a group of graves or a cemetery is treated as a tourism destination then there is 'cemetery tourism'. It should be remembered that what religious and tourism movements have in common is the very fact of setting off on a journey, and using the same elements of infrastructure and means of transport. What is different is the motivation and mode of behaviour (JACKOWSKI 2003). Such tourism may be religious, or religious and educational, with a specific type of tourism generally called religious tourism. Journeys to religious cult centres made for other reasons are a form of cultural or educa- 
zywany na ogół turystyką religijną. Podróże do ośrodków kultu religijnego podejmowane $\mathrm{z}$ motywów pozareligijnych, np. poznawczych, stanowią jedna z form turystyki kulturowej lub poznawczej. Ponadto, jeżeli przyjmiemy tezę, że cmentarz jest również miejscem spacerów i spotkań, to pojawi się motyw rekreacyjny. Na tej podstawie autor dzieli motywy odwiedzin cmentarzy na: religijne, religijno-poznawcze, poznawcze (kulturowe) oraz rekreacyjne.

Przestrzeń geograficzna to przestrzeń mierzalna, obejmująca elementy przyrodnicze powłoki ziemskiej, tj. atmosferę, hydrosferę, biosferę i litosferę oraz trwałe zainwestowanie tej powłoki będące wynikiem działalności człowieka (LISZEWSKI 1995)

Przestrzeń turystyczna to część przestrzeni geograficznej i społeczno-ekonomicznej, w której zachodzą zjawiska turystyczne (WARSZYŃSKA, JACKOWSKI 1978). LISZEWSKI (1995) przestrzeń turystyczną definiuje jako funkcjonalnie wyróżniającą się podprzestrzeń przestrzeni geograficznej rozumianej $\mathrm{w}$ sensie largo, to znaczy jako przestrzeń, na którą składają się elementy przyrodnicze powłoki Ziemi (środowisko naturalne), trwałe efekty działalności ludzkiej w tym środowisku (środowisko gospodarcze), a także środowisko społeczne. Każda z podprzestrzeni geograficznej, w ramach której rozwija się funkcja turystyczna, może być uznana za przestrzeń turystyczną. Przestrzeń turystyczna jest wytworem społecznym, co oznacza, że w określonych warunkach rozwoju cywilizacyjnego przestrzeń ta zostaje uznana za interesującą poznawczo lub rekreacyjnie przez ludność przybywającą $\mathrm{z}$ zewnątrz (LISZEWSKI 1999). Liszewski wyróżnia pięć typów przestrzeni turystycznej: eksploracji, penetracji, asymilacji, kolonizacji i urbanizacji turystycznej. Przestrzeń penetracji jest głównym lub najbardziej tradycyjnym typem przestrzeni turystycznej. Przyjmując, że zabytkowy cmentarz jest częścią przestrzeni geograficznej i obiektem zainteresowań turysty, a więc przestrzenią, w której zachodzą zjawiska turystyczne, możemy założyć, że jest również częścią przestrzeni turystycznej.

Przestrzeń cmentarza, tak jak przestrzeń turystyczna, ulega przemianom, często hierarchicznie. Niewątpliwie cmentarz może stanowić przestrzeń eksploracji i penetracji, a będąc częścią przestrzeni miejskiej, poddany zostaje zewnętrznym procesom urbanizacji. tional tourism. Besides, if it is assumed that a cemetery is also a place for walking and meeting people it will also have a recreational element. Based on this the author divides the motives for cemetery visits into religious, religious and educational, educational (cultural), and recreational.

Geographical space is a measurable space which includes the natural elements of the earth (atmosphere, hydrosphere, biosphere and lithosphere), as well as those resulting from human activity (LISZEWSKI 1995). Tourism space is the part of geographical and socio-economic space where tourism phenomena take place (WARSZYŃSKA \& JACKOWSKI 1978). LISZEWSKI (1995) defines tourism space as a functionally separate sub-space of general geographical space understood as containing natural elements (the natural environment) and the permanent effects of human activity including economic and social environments. Each of the geographical sub-spaces where the tourism function has developed can be regarded as tourism space. Tourism space is a social creation, which means that in given conditions of development it is regarded as of interest from an educational or recreational point of view by people arriving from outside it (LISZEWSKI 1999). Liszewski identifies five types of tourism space: 'exploration', 'penetration', 'assimilation', 'colonisation' and 'urbanisation'. 'Penetration' space is the main or the most typical type of tourism space. Assuming that a historical cemetery is a part of geographical space and the tourist's object of interest (i.e. a space where tourism phenomena occur) it can be assumed that it is a part of tourism space too.

Cemetery space, just like tourism space, undergoes change. Certainly a cemetery can be a space for 'exploration' and 'penetration', and when a part of urban space it is subject to 'urbanisation' processes.

The Old Cemetery at Pęksowe Brzyzko in Zakopane can be taken as an example. It was set up in 1848 and functioned as the only cemetery in Zakopane until 1908. 
T a b e I a I. Rozwój przestrzeni turystycznej cmentarza i zmiany jego funkcji

\begin{tabular}{|c|c|c|c|}
\hline & Przestrzeń miejska & Przestrzeń cmentarza & Funkcja cmentarza \\
\hline $\begin{array}{l}\text { Przestrzeń } \\
\text { eksploracji }\end{array}$ & $\begin{array}{l}\text { Przybysz poszukuje, odkrywa, ba- } \\
\text { da nieznane, nowe tereny. Indywi- } \\
\text { dualne zainteresowanie. Mały } \\
\text { ruch turystyczny. }\end{array}$ & $\begin{array}{l}\text { Cmentarz stanowi miejsce pochówku mieszkańców okolicy. Nie jest } \\
\text { obiektem bezpośrednich zainteresowań turystów. Pojedyncze osoby } \\
\text { odwiedzaja cmentarz w celach poznawczych lub wypoczynkowych. }\end{array}$ & $\begin{array}{l}\text { Grzebalna - podstawowa } \\
\text { Turystyczna - dodatkowa }\end{array}$ \\
\hline $\begin{array}{l}\text { Przestrzeń } \\
\text { penetracji }\end{array}$ & $\begin{array}{l}\text { Przybysz pragnie poznać obiekty } \\
\text { historyczne, zabytkowe, które po- } \\
\text { wszechnie uznawane są za atrak- } \\
\text { cyjne lub motywem jest krótko- } \\
\text { trwały wypoczynek. Ruch tury- } \\
\text { styczny o znaczącej skali (prze- } \\
\text { ważnie zewnętrzny, poza wyjątko- } \\
\text { wymi okresami). }\end{array}$ & $\begin{array}{l}\text { Cmentarz stanowi miejsce ograniczonego pochówku. Nabiera wartości } \\
\text { historycznej. Skupia groby osób ważnych dla lokalnej społeczności. } \\
\text { Pomniki, kaplice, grobowce w całości lub częściowo podlegają ochronie } \\
\text { zabytkowej i konserwatorskiej. Przybysz (często masowy) pragnie } \\
\text { poznać ciekawe, ze względów architektonicznych i historycznych, } \\
\text { obiekty lub miejsca spoczynku sławnych ludzi. Cmentarz jest miejscem } \\
\text { wypoczynku, obiektem zainteresowań krajoznawczych opisywanym } \\
\text { w przewodnikach i promowanym. }\end{array}$ & $\begin{array}{l}\text { Grzebalna - podstawowa, } \\
\text { równorzędna } \\
\text { Turystyczna - dodatkowa, } \\
\text { równorzędna }\end{array}$ \\
\hline $\begin{array}{l}\text { Przestrzeń } \\
\text { urbanizacji }\end{array}$ & $\begin{array}{l}\text { Przekształcenie przestrzeni } \\
\text { niemiejskiej w miejską. }\end{array}$ & $\begin{array}{l}\text { Cmentarz jest atrakcja turystyczną otoczoną przez zabudowania i urzą- } \\
\text { dzenia turystyczne. Powstają obiekty wspomagajace ruch turystyczny } \\
\text { (sklepiki z pamiątkami, dewocjonaliami, szlaki, drogowskazy). Z obsza- } \\
\text { ru peryferyjnego cmentarz staje się obszarem centralnym. Miasto } \\
\text { „wchłania” teren cmentarza. Cmentarz jest obiektem zamkniętym i chro- } \\
\text { nionym. Ogranicza się lub całkowicie zakazuje grzebania zmarłych. }\end{array}$ & $\begin{array}{l}\text { Grzebalna - równorzędna, } \\
\text { dodatkowa } \\
\text { Turystyczna - równorzędna, } \\
\text { przeważająca }\end{array}$ \\
\hline
\end{tabular}

Ż ró dło: Opracowanie własne.

T a b I e I. The development of cemetery tourism space and changes in its function

\begin{tabular}{|l|l|l|l|}
\hline \multicolumn{2}{|l|}{ Urban space } & \multicolumn{1}{c|}{ Cemetery space } & \multicolumn{1}{c|}{ Cemetery function } \\
\hline $\begin{array}{l}\text { 'Exploration' } \\
\text { space }\end{array}$ & $\begin{array}{l}\text { The visitor searches for, dis- } \\
\text { covers and explores new } \\
\text { unknown areas. Individual } \\
\text { interest. Little tourism. }\end{array}$ & $\begin{array}{l}\text { A cemetery is a burial place for local inhabitants, not directly of interest to } \\
\text { tourists. Individuals visit the cemetery for educational or recreational } \\
\text { reasons. }\end{array}$ & $\begin{array}{l}\text { Burial - main } \\
\text { Tourism - additional }\end{array}$ \\
\hline $\begin{array}{l}\text { 'Penetration' } \\
\text { space }\end{array}$ & $\begin{array}{l}\text { Visitors want to see historical } \\
\text { monuments commonly } \\
\text { regarded as attractive, or their } \\
\text { motive is short-term recrea- } \\
\text { tion. Significant tourism } \\
\text { (generally, with few excep- } \\
\text { tions, from outside the area). }\end{array}$ & $\begin{array}{l}\text { A cemetery is a limited burial place and acquires historical significance. It } \\
\text { contains graves of people who were important for the local community. } \\
\text { Monuments, chapels, tombs are under partial or complete historical and } \\
\text { conservation protection. The visitor (often a group visitor) wants to see } \\
\text { architecturally and historically interesting monuments or places where } \\
\text { famous people were buried. The cemetery is a place of recreation, } \\
\text { interesting from the tourism point of view, described in guides and promoted. }\end{array}$ & $\begin{array}{l}\text { Tourism - additional, } \\
\text { equivalent }\end{array}$ \\
\hline $\begin{array}{l}\text { Transforming a non-urban } \\
\text { into an urban space }\end{array}$ & $\begin{array}{l}\text { A cemetery is a tourism attraction surrounded by tourism buildings and } \\
\text { facilities. Facilities supporting tourism activity appear (souvenir shops, } \\
\text { devotional articles, tourism trails and road signs). The cemetery changes } \\
\text { space }\end{array}$ & $\begin{array}{l}\text { Burial - equivalent } \\
\text { additional } \\
\text { area. It is a closed and protected area limiting or totally stopping burials. }\end{array}$ & $\begin{array}{l}\text { Tourism - equivalent, } \\
\text { dominating }\end{array}$ \\
\hline
\end{tabular}

So u r c e: Author.

Za przykład niech posłuży Stary Cmentarz na Pęksowym Brzyzku w Zakopanem. Cmentarz ten został założony w 1848 r. Funkcjonował jako jedyny cmentarz Zakopanego do roku 1908, kiedy to powstał nowy, drugi cmentarz. W roku 1889 pochowano na Pęksowym Brzyzku Tytusa Chałubińskiego. Fakt ten wpłynął na zmianę charakteru cmentarza, gdyż odtąd zaczęto chować zmarłych spośród odwiedzających Zakopane gości (ZDEBSKI 1983). W okresie międzywojennym utrwaliła się zainspirowana wcześniej przez Stanisława Witkiewicza tradycja chowania na Starym Cmentarzu osób zasłużonych dla regionu. Powstały pierwsze
In 1889 Tytus Chałubiński was buried in Pęksowe Brzyzko and this led to a change in its character as from then on visitors who died in Zakopane were buried there (ZDEBSKI 1983). Inspired by Stanisław Witkiewicz, the tradition of burying well-known local people at the Old Cemetery began during the inter-war period and the first historical publications and guides were published. At the end of 1931 the Old Cemetery was placed on the register of historical monuments and at that time was an example of 'exploration' space. 
opracowania historyczne i przewodnikowe dotyczące cmentarza, organizowane są pierwsze akcje propagandowe. Pod koniec 1931 r. Stary Cmentarz w Zakopanem wpisany zostaje do rejestru zabytków. W opisanym okresie mamy na Starym Cmentarzu do czynienia z przestrzenią eksploracji.

Podczas okupacji hitlerowskiej, ze względu na budowę drogi do stacji na Gubałówkę, zmniejszono nieco powierzchnię cmentarza, przesuwając groby i grobowce do centralnej lub zachodniej jego części. Jest to przykład ingerencji miasta w przestrzeń cmentarza poprzez rozwój urbanistyczny Zakopanego.

Cmentarz po wojnie stał się ważnym punktem programu wycieczek do Zakopanego i w Tatry. Zyskał trwałe miejsce $\mathrm{w}$ świadomości zakopiańczyków i miłośników Tatr. Jest podstawowym zwiedzanym obiektem przez przybywających do Zakopanego turystów. Uzyskał miano atrakcji turystycznej. Jest obiektem opisywanym w przewodnikach, elementem propagandy promocyjnej Zakopanego, pojawia się na folderach, widokówkach itp. Cmentarz posiada znaczącą funkcję turystyczną, jest przestrzenią penetracji turystycznej. Otoczony został przez zabudowania i urządzenia turystyczne (zewnętrzna urbanizacja).

Śledząc historię Starego Cmentarza, obserwujemy jednocześnie przemiany funkcjonalne. Od pierwotnej funkcji grzebalnej i pamiątkowej cmentarz zmienił swój charakter i funkcję na turystyczną i symboliczną (tab. I).

\section{WALORY TURYSTYCZNE CMENTARZY}

Jedna $\mathrm{z}$ definicji określa turystykę jako całokształt zjawisk ruchliwości przestrzennej związanych z dobrowolną, czasową zmianą miejsca pobytu, rytmu i środowiska życia oraz $\mathrm{z}$ wejściem w styczność osobistą ze środowiskiem odwiedzanym (przyrodą, kulturą lub społeczeństwem) (PRZECŁAWSKI 1979). Turystyka jest spotkaniem kultur. Jest wymianą wartości pomiędzy turystami a mieszkańcami. Może być czynnikiem przemian społecznych i kulturowych.

Cmentarze są częstym celem ruchu turystycznego odbywającego się $\mathrm{w}$ ramach turystyki poznawczej o motywach krajoznawczych. Do grupy walorów krajoznawczych RoGALEWSKI (1979) zalicza m.in. charakterystyczne zespoły krajobrazowe i osobliwości przyrody, określane terminem
During the Nazi occupation, due to the construction of a road to the cable car station for Gubałówka, the cemetery area was reduced and graves and tombs moved into its central or western part. This is an example of local authority interference with cemetery space through the urban development of Zakopane.

After the war the cemetery became an important element in trips to Zakopane and the Tatra Mountains, lying deep in the awareness of Zakopane inhabitants and Tatra mountain lovers. It is visited by tourists to Zakopane and is a tourism attraction, is described in guides and appears as a promotional element of Zakopane in brochures, on postcards, etc. The cemetery performs a significant tourism function as an example of 'penetration' space and is surrounded by tourism buildings and facilities spreading 'urbanisation'. This history reveals the functional changes of the old Cemetery from burial and commemorative to tourism and symbolic functions (table I).

\section{THE TOURISM RESOURCES OF CEMETERIES}

One definition describes tourism as all phenomena concerning movement in space connected with a temporary voluntary change of location and of rhythm of life and environment, as well as in personal contact with the visited environment (natural, cultural or societal) (PRZECŁAWSKI 1979). Tourism is a meeting of cultures, an exchange of values between tourists and local inhabitants and can be a factor in social and cultural change.

Cemeteries are frequently the goals of educational tourism. Among tourism resources, ROGALEWSKI (1979) mentions typical landscape complexes and natural curiosities - natural environment resources; as well as monuments of architecture, art, 
walorów środowiska przyrodniczego oraz zabytki budownictwa, sztuk plastycznych, kultury materialnej, pamiątki historyczne, tj. walory dóbr kultury. Obie kategorie walorów spotykamy na wielu cmentarzach.

Część społeczeństwa odwiedza cmentarz w celu uporządkowania grobu bliskich, spotkania duchowego, jednocześnie nie ,z obowiązku” a „dla przyjemności”, w celu wypełnienia wolnego czasu, wykorzystania sprzyjającej spacerom pogody, w celu regeneracji sił psychicznych i fizycznych, spotkań towarzyskich, a więc $\mathrm{w}$ ramach ,wypoczynku i rekreacji”. W grupie walorów wypoczynkowych niezbędne są cechy stanowiące minimum warunków do wypoczynku (WYRZYKOWSKI 1975). Do takich cech zaliczyć można m.in. czyste powietrze, ciszę, niski stopień urbanizacji, walory estetyczne krajobrazu, brak zasadniczych przeciwwskazań klimatycznych, korzystne warunki bioklimatyczne. Większość zabytkowych zespołów cmentarnych, będących terenami zielonymi o założeniach parkowych, takie warunki spełnia.

Wiele organizacji samorządowych powołanych w celu stworzenia warunków dla rozwoju turystyki lokalnej wykorzystuje stare cmentarze do ce-lów promocyjnych. Cmentarze z okresu I wojny światowej są $\mathrm{w}$ obecnej chwili jednym $\mathrm{z}$ atutów krajoznawczych, np. Gorlic, Sękowej, Uścia Gorlickiego w Beskidzie Niskim. Wizerunki pomników cmentarnych pojawiają się $\mathrm{w}$ folderach reklamowych, w wydawnictwach promocyjnych czy przewodnikach.

Podstawą rozwoju turystyki, poza ogólnymi warunkami społeczno-ekonomicznymi, jest ranga i rodzaj walorów turystycznych (przyrodniczych, antropogenicznych) oraz stopień ich wykorzystania. $\mathrm{Na}$ podstawie tych kryteriów turystyka może pełnić funkcje główną, równorzędną, uzupełniającą bądź dodatkową (WARSZYŃSKA 1999). Podstawowa grzebalna funkcja cmentarza może przejść w peryferyjną, na rzecz równorzędnej, uzupełniającej lub dodatkowej funkcji turystycznej.

Cmentarz, będący obiektem wycieczek, coraz częściej pojawia się w turystyce etnicznej. GAWORECKI (2000) zwraca uwagę na pamiątki historyczne pozostałe po licznych zmaganiach wojennych, m.in. cmentarze wojenne, a także swoiste nekropolie ofiar ludobójczej działalności hitleryzmu (Oświęcim, Majdanek, Sztutowo, Rogoźnica). Na terenie Polski ważnymi obiektami odwiedzanymi przez turystów etnicznych są cmenta- culture and history - cultural resources. Both categories can be found at many cemeteries.

Some visit a cemetery in order to clean a relative's grave or to have a 'spiritual meeting', not as a duty but for pleasure, to spend free time, make use of good weather, go for a walk, to recuperate mentally and physically, and meet family or friends. Thus the visits are a form of recreation and when considering recreational resources it is essential that minimum conditions are met (WYRZYKOWSKI 1975): clean air, silence, limited urbanisation, aesthetic landscape features, good climatic and favourable bioclimatic conditions. The majority of historical cemetery complexes are park type areas and meet these requirements.

Many organisations set up to create conditions for local tourism development use old cemeteries for promotional purposes. Cemeteries from World War I are at present tourism resources in e.g. Gorlice, Sękowa and Uście Gorlickie in the Beskid Niski. Pictures of cemetery monu-ments appear in tourism brochures, and in promotional publications and guides.

The basis for tourism development, apart from socio-economic conditions, is the quality and type of tourism resource (natural and anthropogenic) as well as the extent to which they are exploited. On the basis of these criteria tourism can perform the 'main', an 'equivalent', a 'complementary' or an 'additional' function (WARSZYŃSKA 1999). The 'main' function of a cemetery, a burial, may become peripheral and change into an 'equivalent', 'complementary' or 'additional' tourism function.

Being a tourism destination, a cemetery increasingly often appears in ethnic tourism. GAWORECKI (2000) points to historical memorials such as war cemeteries, as well as particular necropolises for the victims of Nazi extermination policy (Oświęcim, Majdanek, Sztutowo and Rogoźnica). Evangelical cemeteries are important places for ethnic tourists in Poland due to the massive population displacement after World War II, and Jewish cemeteries due to the extermina- 
rze ewangelickie i żydowskie ze względu zarówno na liczne wysiedlenia w okresie po 1945 r., jak i eksterminację ludności żydowskiej podczas II wojny światowej. Zabytki sepulkralne posiadają wysokie wartości emocjonalne, historyczne i artystyczne. Nekropolie, uporządkowane i udostępnione do zwiedzania moga stanowić dużą atrakcję turystyczną dla turystów z zagranicy, którzy poszukują swoich korzeni, miejsc pochodzenia, urodzenia i zamieszkania $\mathrm{w}$ przeszłości ich samych, jak i przodków.

\section{ATRAKCYJNOŚĆ TURYSTYCZNA CMENTARZY WOJENNYCH BESKIDU NISKIEGO}

Przykładem cmentarzy stanowiących atrakcję turystyczną są cmentarze wojenne z okresu I wojny światowej w Beskidzie Niskim (TANAŚ 1996).

W latach 1915-1918 na obszarze ówczesnej Galicji pochowano 61 tys. żołnierzy, zbudowano ogółem 378 cmentarzy, z czego 64 na terenie Beskidu Niskiego. Cmentarze miały być wyrazem wdzięczności monarchii Austro-Węgierskiej wobec poległych żołnierzy za ich męstwo, poświęcenie i śmierć. Miały stać się niemym pomnikiem przypominającym następnym pokoleniom o tragedii narodów i śmierci tysięcy.

Dziś cmentarze wojenne są jedną $\mathrm{z}$ atrakcji turystycznych Beskidu Niskiego, odwiedzane przez rzesze turystów indywidualnych i grupowych. Potwierdzaja to przeprowadzone przez autora w latach 1995-1997 badania nad atrakcyjnością turystyczną cmentarzy wojennych w Beskidzie Niskim oraz stopniem ich znajomości przez przyjezdnych turystów i stałych mieszkańców.

$\mathrm{Na}$ opisywanych cmentarzach było aż 77\% ankietowanych turystów, $75 \%$ tej grupy deklarowało uprawianie turystyki górskiej dłużej niż 5 lat. $60 \%$ ankietowanych znało okoliczności budowy cmentarzy i historię bitwy gorlickiej. Interesująco przedstawiały się odpowiedzi na pytanie „Czy cmentarze wojenne mogą być atrakcją turystyczną?", 75\% badanych odpowiedziało twierdząco. Cmentarze wojenne były na ogół znane również stałym mieszkańcom. $80 \%$ ankietowanych mieszkańców wskazywało, że cmentarze są odwiedzane przez turystów. $68 \%$ ankietowanych mieszkańców uznało omawiane cmentarze za tion of the Jewish population during the war. Sepulchral monuments have strong emotional, historical and artistic value. Such necropolises, renovated and open to visitors may be a big attraction for tourists from outside Poland in search of roots, places of birth and where they and their ancestors used to live.

\section{THE TOURISM ATTRACTIVENESS OF THE BESKID NISKI WAR CEMETERIES}

The author has previously given the war cemeteries from World War I in the Beskid Niski (TANAŚ 1996) as an example of a cemetery tourism attraction. Between 1915 and 1918 in the area of Galicia 61000 of soldiers were buried and 378 cemeteries built, 64 of which can be found in the Beskid Niski. The cemeteries were intended to be an expression of gratitude on the part of the Austro-Hungarian Monarchy to the dead soldiers for their bravery, devotion and death. They were to become a mute monument to remind future generations about the tragedy of nations' and the deaths of thousands.

Today the war cemeteries are a tourism attraction of the Beskid Niski visited by large numbers of individual and group tourists. This was confirmed by the author's research among tourists and local inhabitants into knowledge about them and their tourism attractiveness in 1995-1997.

The cemeteries were visited by $77 \%$ of the tourists approached, $75 \%$ of whom claimed that they had been visiting for longer than five years. $60 \%$ knew the circumstances in which the cemeteries were built and the story of the battle of Gorlice. To the question: "Can war cemeteries be a tourism attraction?" - 75\% agreed. The majority of local inhabitants were also familiar with the war cemeteries, $80 \%$ said they were visited by tourists, and $68 \%$ considered the cemeteries a tourism attraction of the Beskid Niski. 
„atrakcję turystyczną” Beskidu Niskiego.

Wyniki przeprowadzonych badań wskazują na cmentarze wojenne Beskidu Niskiego jako istotny walor turystyczny będący ważną składową atrakcyjności turystycznej tego obszaru. Badania potwierdzają tezę o zainteresowaniu turystów cmentarzami wojennymi oraz wykorzystanie cmentarzy w procesie promocji turystycznej obszaru Beskidu Niskiego, prowadzonej przez władze samorządowe i organizacje wspierające rozwój turystyki.

\section{ZAKOŃCZENIE}

Podsumowując rozważania warto przytoczyć kilka danych dotyczących percepcji cmentarzy w zależności od zmiany wieku ankietowanych osób. Poniższe wyniki oparte zostały na badaniach przeprowadzonych w roku 2004 na grupie 310 osób w przedziale wiekowym od 13 do 60 roku życia.

W odpowiedziach na pytanie „Czy był Pan/Pani na cmentarzu w ramach wolnego czasu i wypoczynku?" widoczna była istotna rola wieku ankietowanych osób i związanych $\mathrm{z}$ tym zmian, jakie zachodzą w postrzeganiu cmentarza. Otóż młodzież szkolna do 24 roku życia w większości (powyżej $50 \%$ ) odpowiadała negatywnie. Natomiast w grupie osób powyżej 25 roku życia obserwowano przewagę w odpowiedziach twierdzących (56\%). Często osoby starsze postrzegały cmentarz jako miejsce spełniające rolę parku, miejsce sprzyjające regeneracji sił. Na pytanie „Czy był Pan/Pani kiedykolwiek na cmentarzu z wycieczką lub indywidualnie w celu zwiedzenia obiektu?" zdecydowana większość odpowiedzi $\mathrm{w}$ badanej populacji była pozytywna (w przedziale 57-88\%). Na pytanie „Czy zgadza się Pan/Pani z twierdzeniem ,zabytkowy cmentarz jest atrakcyjny turystycznie?", w którym autor celowo wyselekcjonował charakter cmentarza - cmentarz zabytkowy, a więc cmentarz postrzegany nie tylko jako miejsce współcześnie użytkowane, kojarzące się z grobami bliskich, ale jako obiekt historyczny, posiadający walory poznawcze. Na tak postawione pytanie zdecydowana większość odpowiadała twierdząco, niezależnie od wieku (średnio ok. $68 \%$ odpowiedzi twierdzących).

Z przytoczonych wyżej wyników badań ankietowych oraz analizy teoretycznej wynika, że cmentarz może być obiektem zainteresowań turysty, tym sa-
On the basis of the research results, the author showed that the war cemeteries of the Beskid Niski are a significant tourism resource and an important component of the tourism attractiveness of this region. The research confirmed that tourists are interested in war cemeteries and points to the use of the cemeteries for the purposes of tourism promotion by local authorities and organisations supporting tourism development.

\section{FINAL REMARKS}

Finally, some data regarding the perception of cemeteries according to age group based on research in 2004 among 310 respondents aged between 13 and 60 .

In answers to the question "Have you been to a cemetery in your free time or on holiday?" it was easy to see the significance of age and its effect on perception. For students up to 24 over $50 \%$ answered 'no', while in the group over $2556 \%$ answered 'yes'. Older people often saw a cemetery as a parklike place leading to relaxation. Answers to the question: "Have you ever been to a cemetery on an excursion or individually for sightseeing purposes?" were mostly 'yes' in all groups (57-88\%). To another question: "Do you agree with the statement that a historical cemetery is touristically attractive?", where the author intentionally singled out the historical character of the cemetery so that it was perceived not only as a presently used facility associated with the graves of family and friends, a large majority (on average 68\%) answered 'yes' regardless of age.

These questionnaire results and the theoretical analysis show that a cemetery can be interesting for the tourist, and at the same time as a tourism resource it can determine the tourism attractiveness of a given place or area, provided it has significant historical, cultural, artistic or natural qualities. Not every cemetery then, and especially not new ones, have tourism resources 
mym może jako walor turystyczny stanowić o atrakcyjności turystycznej danego miejsca lub obszaru pod warunkiem posiadania istotnych cech historycznych, kulturowych, artystycznych lub przyrodniczych. Nie każdy więc cmentarz, a w szczególności cmentarz nowo założony i współczesny, posiada walory turystyczne i stanowi cel wycieczek krajoznawczych. Znaczenie cmentarza może ulec zmianie, wówczas gdy pochowana zostanie na nim osoba powszechnie uznawana za autorytet, ceniona lub znana za życia.

Pamiętając o inskrypcji znajdującej się na bramie Starego Cmentarza w Zakopanem „Ojczyzna to ziemia i groby. Narody tracąc pamięć tracą życie", powinniśmy rozpowszechniać wiedzę o cmentarzach i powiększać świadomość społeczeństwa w tym zakresie. Doskonałym tego sposobem w opinii autora jest turystyka krajoznawcza. or are destinations. The significance of a cemetery can change when someone commonly regarded as an authority, respected or well known, is buried there.

Remembering the inscription on the Old Cemetery gate in Zakopane: " $A$ fatherland is found in its soil and its graves. In the loss of memory a nation loses its life", knowledge of cemeteries should be popularised and society made aware of their importance. This can be successfully achieved by means of tourism.

\section{BIBLIOGRAFIA - BIBLIOGRAPHY}

BAŃKO M. (red.), 2003, Wielki słownik wyrazów obcych, PWN, Warszawa.

BAŃKOWSKI A., 2000, Etymologiczny słownik języka polskiego, PWN, Warszawa.

DuBisz S. (red.), 2003, Uniwersalny słownik języka polskiego, PWN, Warszawa.

GAWORECKI W., 2000, Turystyka, PWE, Warszawa.

JACKOWSKI A., 2003, Święta przestrzeń świata. Podstawy geografii religii, Wyd. UJ, Kraków.

Kolbuszewski J., 1996, Cmentarze, Wyd. Dolnośląskie, Wrocław.

KRUCZeK Z., 1997, Metodyka krajoznawstwa, AWF, Kraków.

LiJewski T., MikuŁowski B., WyRzykowski J., 1992, Geografia turystyki Polski, PWE, Warszawa.

LISZEWSKI S., 1973, Użytkowanie ziemi $w$ miastach woj. opolskiego, Instytut Şlaski, Opole.

Liszewski S., 1995, Przestrzeń turystyczna, „Turyzm”, t. 5 , z. 2.

LiszewsKI S., 1999, Przestrzeń turystyczna miasta (przykład Łodzi), „Turyzm”, t. 9, z. 1.

MACZUBSKI T., 1989, Zasady inwentaryzacji krajoznawczej cmentarzy, Zarzad Główny PTTK, Warszawa.

PRZECŁAWSKI K., 1979, Socjologiczne problemy turystyki, Warszawa.
PRZEClAwski K., 1987, Turystyka i jej rola we współczesnym świecie, „Problemy Turystyki”, nr 3 (37).

PRZYBYSZEWSKA-Gudelis R., GRABISZEWSKI M., IWICKI S., 1979, Problematyka waloryzacji $i$ zagospodarowania turystycznego $w$ Polsce, Instytut Turystyki, Warszawa.

ROGALEWSKI O., 1979, Zagospodarowanie turystyczne, WSiP, Warszawa.

TANAŚ S., 1996, Walory turystyczne cmentarzy wojennych $z$ okresu I wojny światowej w Beskidzie Niskim, maszynopis pracy magisterskiej wykonanej w Katedrze Geografii Miast i Turyzmu UŁ, Łódź.

WARSZYŃSKA J., 1986, Problemy badawcze geografii tury$z m u$, „Folia Geographica”, ser. Geographica Oeconomica, t. 19, PAN, Kraków.

WARSZYŃSKA J., 1999, Główne problemy badawcze geografii turyzmu, „Turyzm”, t. 9, z. 1 .

WARSZYŃSKA J., JACKOWSKI A., 1978, Podstawy geografii turyzmu, PWN, Warszawa.

WYRZYKOWSKI J., 1975, Walory wypoczynkowe środowiska przyrodniczego Polski $w$ świetle aktualnego stanu badań, „Zeszyty Naukowe Instytutu Turystyki”, nr 2/3.

ZDEBSKI J., 1983, Cmentarz zasłużonych $w$ Zakopanem, Kraj, Warszawa-Kraków. 